\title{
Editorial - Precarity, Platforms, and Agency: The Multiplication of Chinese Labour
}

Chris King-chi Chan, Éric Florence and Jack Linchuan Qiu

\section{(2) OpenEdition}

\section{Journals}

Electronic version

URL: https://journals.openedition.org/chinaperspectives/11268

DOI: 10.4000/chinaperspectives. 11268

ISSN: 1996-4617

\section{Publisher}

Centre d'étude français sur la Chine contemporaine

Printed version

Date of publication: 1 March 2021

Number of pages: 3-7

ISSN: 2070-3449

\section{Electronic reference}

Chris King-chi Chan, Éric Florence and Jack Linchuan Qiu, "Editorial - Precarity, Platforms, and Agency: The Multiplication of Chinese Labour", China Perspectives [Online], 2021/1 | 2021, Online since 01 March 2021, connection on 02 April 2022. URL: http://journals.openedition.org/chinaperspectives/ 11268 ; DOI: https://doi.org/10.4000/chinaperspectives.11268 


\title{
Precarity, Platforms, and Agency: The Multiplication of Chinese
} Labour

\author{
CHRIS KING-CHI CHAN, ÉRIC FLORENCE, \\ AND JACK LINCHUAN QIU
}

\footnotetext{
I
} want my blood and sweat money back" (Wo yao wode xuehan qian 我要我的血汗錢): these are the words of Liu Jin 劉進, a 47-year-old delivery rider who worked for Ele.me, Alibaba's food-delivery platform, when he set himself on fire in early January 2021. ${ }^{1}$ This tragic event, which sparked heated discussions on the Chinese social media, was preceded by the death of a 22-year-old employee at Pinduoduo, another e-commerce company claiming more than 700 million users in China. As the company announced it would pay a 2,000 RMB ${ }^{2}$ sum to the family as compensation for its employee's death, a backlash quickly ensued on social media, forcing Pinduoduo to turn the initially announced amount into 600,000 RMB. A few days later, another Pinduoduo employee committed suicide in Changsha. In public debates that followed, these three events were associated with the ruthless "996" overtime corporate culture nurtured by giant tech companies in China, as well as in many other parts of the world. More significantly, these cases hint at unfolding processes that not only characterise the twenty-first century platformisation of the Chinese economy, but also point at broad processes of diversification and intensification of labour regimes in China and elsewhere.

\section{The global trend of precarious employment}

Over the last two decades, labour scholars have shed light on global patterns of deregulation of employment relationships, as well as corresponding processes of fragmentation of working-class politics, initially predominant in Western Europe (Standing 2011; Kelleberg and Hewison 2018; Atzeni and Ness 2018). While irregular patterns of employment were originally quite widespread in much of East Asia, a regional trend is seen towards informalisation of labour going through increasing unpredictability and experiences of "permanent impermanence" for an ever-wider spectrum of workers (Chang 2009; Friedman and Lee 2010; Qiu 2016; Pun 2016; Kelleberg and Hewison 2018; Lazar and Sanchez 2019).

In twenty-first-century China, as Pun and Smith (2018) have highlighted, along with more protective labour regimes for a small portion of the regular workforce, the very legislation aimed at protecting these workers has also offered venues for the creation of an increasing number of non-regular forms of employment such as students, dispatch or agency workers, service workers, daily-wage labourers, and the upsurge in platform-based gig workers. Moreover, national labour regulations have on the whole not been fully enforced by local governments. Hence, casualisation remains rampant, as job security and provision of social welfare have not become the norm despite the establishment of more comprehensive and protective labour legislation. To add to this complex mosaic, recent patterns of digitalisation and automation of the economy have ushered in an all-encompassing process of flexibilisation and deregulation of employment relations, further blurring the boundaries between various forms of regular and irregular employment.

\section{Labour agency in a changing labour market}

Labour relations within factories have up to recently been the chief focus of much of Chinese and foreign social sciences scholarship, ${ }^{4}$ documenting patterns of workers' collective organisation and the role of grassroots labour organisations in collective action (Lee 2007; Pun and Lu 2009, 2010; Chan 2010). The insights of this body of scholarship have oscillated between two main lines of argument. On the one hand, a general pattern towards a greater capacity for workers to organise, mediate and visibilise their claims and collective action, as well as a growing class- and rights-consciousness among the second generation of rural migrant workers have been highlighted (Chan 2010; Pun and Lu 2009; Pun and Smith 2018; Froissart 2018; Yu and Hu 2013). On the other hand, a concurrent argument has been made that the predicaments that keep workers in overly subaltern positions remain unchallenged (Lee 2016; Franceschini 2017; Swider 2017).

China's integration into the global economy after 1978 created a large number of precarious workers, the vast majority of whom are rural-urban migrants. In the private sector, this has led to an abundance of cheap labour and a prevalence of despotic management styles and poor working

1. "Chinese courier sets fire to himself in protest over unpaid Alibaba wages," The Financial Times, 12 January 2021, https://www.ft.com/content/d6189ee8-9aea-41dd-a412-b8daba9cacf2 (accessed on 18 January 2021).

2. "Overtime Culture Back in the Spotlight After Pinduoduo Employee's Death", Sixth Tone, 4 January 2021, https:/www.sixthtone.com/news/1006661/overtime-culture-back-in-spotlight-afterpinduoduo-employees-death (accessed on 18 January 2021).

3. 996 refers to working from 9.00 am to $9.00 \mathrm{pm}$ six days a week.

4. Exceptions to this focus on industrial relations are for instance Pun and Xu (2011), Caron (2013), Gaetano (2015), Swider (2015), Xue and Huang (2015), Zavoretti (2018), and Sun (2019) who have focused on other categories such as construction workers, domestic workers, street-vendors, etc. 
conditions (Chan 2001). Meanwhile, the privatisation of SOEs resulted in millions of laid-off workers in the 1990s (Cook 2005). As a result, various types of non-standard and precarious employment have emerged in the labour market (Friedman and Lee 2010). In the late 1990s, workers staged significant protests against the state's initiative to privatise stateowned-enterprises (SOEs) or demanded proper compensation for layoffs and pensions. However, as SOE workers failed to challenge the wave of privatisations, their number has declined, and workplace conflicts have become less common in SOEs since the early 2000s. In contrast, strikes and other forms of protest have emerged amongst migrant workers, especially in South China (Chan 2010).

The escalation of labour unrest forced the government to rebalance labour relations through labour legislation. The first national Labour Law has been effective since 1995 as a framework for basic labour rights protection. The Labour Contract Law was then introduced in 2007 to stabilise and regulate employment relations by making written contracts a legal obligation for employers. However, a more significant wave of strikes led by Honda workers in Foshan, Guangdong Province, attracted global attention in June 2010. These strikes gave impetus to the process of trade union reform as the All-China Federation of Trade Unions (ACFTU), the official trade union centre, began to promote trade union direct elections and collective bargaining for wages in some of the enterprises in which strikes took place (Chan and Hui 2014).

This development might have created optimism over raising workers' consciousness and the potential of labour agency to pressure state and management (Pun and Lu 2009; Chan 2010: Froissart 2018). However, the Chinese labour movement has experienced "one step back," in the words of Elfstrom (2019), since President Xi Jinping took to power and the party-state adopted a hard-line policy over civil society (Howell and Pringle 2019). Meanwhile, the Chinese economy has slowed down since 2012, with many factories closing and relocating to Southeast Asia. In the face of economic slowdown, the state has lowered the standard of labour rights protection. Labour protests that affected public order or urban traffic have been directly shut down. At the end of 2015, a dozen NGO leaders in Guangzhou and Foshan were arrested by the police, and four of them were subsequently charged with crimes (Chan 2020).

During this period, the state has been encouraging the growth of the service sector as a new channel to provide job opportunities for migrant workers when traditional manufacturing jobs are in decline. In 2018, service industries accounted for more than $46.3 \%$ of total employment, while agriculture and industry represented approximately $26.1 \%$ and $27.6 \%$, respectively (Chan 2020). Research has found that labour regulations that protect the basic rights of workers, such as the Social Insurance Law introduced in 2011 to guarantee workers' entitlements to medical, work injury, maternity, pension, and unemployment insurance, have not been well implemented in the service sector, compared to the manufacturing sector (Wang et al. 2020).

This was the context for the rapid emergence of the new, Internetbased platform economy in China. According to an official source, ${ }^{5} 75$ million workers worked in the Internet and digital economy in 2018, only slightly less than the number of workers in the manufacturing sector. The development of the platform and digital economy has reinforced the trend of informalisation in the labour market. Many platform workers are not regarded as direct employees of platform companies and so are excluded from the protection of employment laws. Studies have also reported long working hours, low piece rates, and algorithm-controlled labour processes associated with platform jobs (Wu et al. 2019; Sun 2019).

The trend of precarisation in the service sector, in particular the platform economy, seems to provide evidence for the argument of persistent predicamental working conditions for migrant workers (Lee 2016; Franceschini 2017; Swider 2017). Nevertheless, the dramatic growth of the third sector in China has also resulted in surging labour unrest in the service sector. Workers' collective actions in the service industries have accounted for $21 \%$ of all collective action cases, surpassing the manufacturing industries for the first time in the third quarter of 2016, according to a report by China Labour Bulletin. ${ }^{6}$ In 2020, international media turned their attention to an industrial action organised by Chinese express delivery workers before Singles' Day (11 November), the online shopping event promoted by e-commerce giant Alibaba. ${ }^{7}$ Like their counterparts in the factories, platform labourers are able to exercise their collective power during the peak season for their industry. Debate over the potential and limitations of labour agency in the Chinese context will continue (Chen et al. 2019). In a recent publication, Lei (2020: 1) argues that "platform architecture reinforce one another, escalating grievances, enhancing the appeal of collective contention, and providing spaces for mobilizing solidarity and collective action." This has further suggested the potential of labour agency in the Chinese platform economy. ${ }^{8}$

\section{Contents and insights of the special issue}

Against this background, this special issue of China Perspectives has set out not to focus on workers' collective action and agency within factories per se. Rather, drawing from Swider's suggestion to include the heterogeneity of informal labour into the study of working-class politics in China (2017), it seeks to explore forms of workers' creativity and agency that move beyond workshop-based traditional forms of collective activism and labour organising. Hence, the contributors to this special issue, each in specific ways, address the following questions: Under the current processes of flexibilisation and informalisation such as the platformisation of the economy and society, what forms of empowerment or agency (individual and collective) are being crafted and struggled for, from minimising the everyday effects of systems of exploitation and domination to more visible forms of labour politics? How do processes of precarisation and informalisation transform the very organisation of production and shape emerging forms of employment and labour relations?

All three papers draw on extensive first-hand empirical research and provide theoretically-informed insights into the transformation of forms of employment, of modes of production, and of workers' everyday struggles and agency. In the opening contribution to this special issue,

5. Sharing Economy Research Center of State Information Center, “中國共享經濟發展年度報告 (2019)" (Zhongguo gongxiang jingji fazhan niandu baogao (2019), China Sharing Economy Annual Report (2019)), http://www.sic.gov.cn/News/557/9904.htm (accessed on 21 January 2021).

6. "As China's economy shifts to services in Q3, so too does labour unrest," China Labour Bulletin, 2016, https://www.clb.org.hk/content/china\%E2\%80\%99s-economy-shifts-services-q3-so-toodoes-labour-unrest (accessed on 21 January 2021).

7. "On Singles' Day in China, Couriers Clamor for More," The New York Times, 11 November 2021, https://www.nytimes.com/2020/11/11/business/alibaba-singles-day-couriers.html (accessed on 21 January 2021).

8. De Kloet et al. similarly argue that platformisation enables both increased exploitation and possibilities for empowerment (De Kloet et al. 2019: 253-4). 
drawing on Mezzadra and Neilson's concept of "multiplication of labour" and "border struggles," Mao Jingyu explores how processes of "diversification" and "intensification" of labour provide a useful lens to study the increasingly blurred boundaries between workers' lives and their work among ethnic performers in Yunnan, Southwest China. Through her ethnographic fieldwork carried out during 2016-2017 at three ethnic restaurants, Mao shows how workers engage in border struggles by engaging the increasingly pervasive colonisation of work into their private and sometimes most intimate lives. As a response to this process of intensification of labour, ethnic performers manage to draw on multilayered normative narratives (elite, state-sponsored, market-related, etc.) in their expected gender, ethnic, and class roles. They thereby engage in giving meaning to their experiences as well as in dialectic processes of subject-making (being made and self-making). Strictly speaking, Mao's study is not about the digital platform economy. But as Gillespie (2010) points out, the neologism of "platform" is intentionally created and manipulated through a political act by tech giants such as Google to maximise corporate interests. The terminology is therefore arbitrary and malleable, referring to quite different economic sectors from online content (e.g., YouTube) to offline services (e.g., food delivery). Back to the context of Mao's study, her "platform" is the place designed and used for entertainment performance, a stage or "platform" in an older sense for a performing art of entertainment that is ethnicised and exoticised. It is on this commercialised "platform" that Mao examines border-crossing between work and play, gendered distance and intimacy, personal life and workers' agency.

In the second paper, based on empirical qualitative data gathered between 2017 and May 2020, Sun and Chen shed light on the still underresearched topic of workers' agency in one of the fastest expanding and highly attractive sectors to many rural workers initially employed in the construction or manufacturing industries: the digitally-mediated fooddelivery sector, which employs more than 6 million riders today. They depict how the largely unregulated field of the platform-mediated fooddelivery industry has produced various categories of delivery workers with different forms of management, employment relations, and labour conditions. Interestingly, the two authors document a vast heterogeneity within the very sector of food-delivery itself, not to mention further variations in employment forms within and among other sectors such as the one Fan describes in her contribution to this special issue. Departing from the binary opposition between domination and resistance, they draw on the notion of "contingent agency" to show how, facing the predicaments of the pervasive and individualising power of algorithms aimed at constant measurement of workers' output, riders draw from both their understanding of the technological dimensions within the "platform-mediated logistical chain" and from their "networked relations among the platforms, intermediaries, restaurants, and workers," which to a large extent introduce new factors to shape workers' subjectivities, identities, and the way in which they exercise and perform their agency" (see Sun and Chen's article in this issue). Hence, they depict a very interesting and multi-layered feature of delivery-workers' agency, the fact that it is at once individualised (there is no co-presence of workers) and networked. In this way, Sun and Chen go beyond the heuristically poor "false consciousness debate" by documenting the dialectics at play in workers' subjective and effective accommodation of the uncertainty and precariousness embedded in the platform economy. They eventually underline the limited social mobility and possibilities for skills upgrading of delivery workers, a feature they share with the young generation of rural workers.

Drawing on data gathered from fieldwork done in five garment manufacturing and sales centres between 2018 and 2020 in the provinces of Guangdong, Zhejiang, and Jiangsu, Fan Lulu addresses another unexplored topic, i.e., the impact of the platform economy on the structure of supply chains and value chains, as well as its effects on the forms of organisation of production and labour relations within the garment manufacturing industry. Fan describes how the great volatility and strong reliance on ever-shifting consumer demands have caused the initially vertically-integrated clothing production units to give way to a great number of small production workshops with extremely informal employment forms, such as daily-wage workers hired through verbal agreements on casual labour markets, and skilled married couples labouring in family workshops. Fan points to the fact that major platform companies make huge profits by gathering highly valuable consumerrelated data and by transferring production costs and risks to workers. Despite these extremely precarious and informal labour conditions, an increasing number of garment workers choose to become self-employed (daily-wage) workers in return for higher revenues and greater autonomy in their control over employment and management of their daily lives.

Mezzadra and Neilson (2013), who have inspired of the theme of this special issue, were invited to write an afterword for this collection. They emphasise that the China story played an important role in the analysis of their book Border as Method. The industry structure of China has changed dramatically since the book was published. However, as Mezzadra and Neilson point out, there is no sign that China is evolving in the direction of "standard labour relations." Instead, the three papers in this special issue have further supported the notion of "intensification, diversification, and heterogenisation of labour," the three dimensions that they call "multiplication of labour."

We would like to next highlight a few common insights of the contributions of this special issue. Firstly, the three papers compare a diversity of informal statuses of workers with the labour conditions of workers in the traditional manufacturing and construction industries. They all highlight the atomisation of the figure of the traditional workersubject, with collective mobilisation depicted not as impossible but as severely constrained by ever-shifting structural forces. They also all point to the precariousness and vulnerability of workers' conditions, as well as to their everyday struggles for agency, an agency that is never permanent as workers' strategies are often swiftly integrated into the workings of dynamic structures of domination.

Secondly, the contributions by Sun and Chen and by Fan point to an interesting paradoxical trend: a growing number of rural migrant workers originally employed in the traditional manufacturing and construction sectors are increasingly turning to the unprotected, highly informal platform-mediated sectors in return for greater autonomy in their work and private life, as well as higher wages. In this respect, as Fan aptly notes in her paper, despite the Chinese economy's transformation towards digitalisation at the level of marketing and sales, and the quest for upward trends in the value chain, the reliance on extremely informal forms of employment in parallel to more formal and standardised production and labour regimes such as those turned chiefly towards export remains very strong indeed. Such a combination of various forms of organisation of production and labour forms, producing continuums of statuses from formal to fully informal workers, echoes a core feature in the history of 
global capitalism, i.e., that such a co-existence has been and remains key to global capitalism's re-deployment and resilience.

Thirdly, the three papers offer insights for further research on the issue for which a theoretical and conceptual framework should be crafted in order to study increasingly individualised and fragmented labour politics as well as processes of workers' valuation and hierarchisation, and workers' attempts at undermining the effects of such processes.

The three papers all speak to what Mezzadra and Neilson have called the "multiplication of labour," which is made possible through processes of "intensification" (longer hours, increasing flexibility, and the pervasive colonisation of workers' lives), "diversification" (global capitalism's reliance on and shaping of a diversity of forms of labour), and "heterogenisation" (the creation of ever-more complex arrangements of political economy and law). Altogether, the contributions gathered here provide fresh insights into how these processes affect workers' lives and their politics in China. Despite differences in structural factors shaping precarity in the various contexts - be they ethnic tourism, food delivery, or garment manufacture - a most important, thematic finding is the emergence of workers' agency even in unexpected places of disempowerment. Every cloud has a silver lining. Every platform cultivates agency beyond precarity. The struggles of multiplication continue.

\section{Acknowledgements}

I This special issue is developed from an international workshop on "Agency in an Era of Multiplication of Labour Regimes," organised by the Centre for Social Innovation Studies at the Chinese University of Hong Kong (CUHK) and the French Centre for Research on Contemporary China (CEFC) on 24 June 2019. We are grateful to the authors and participants in the workshop, and to the editors and anonymous reviewers of China Perspectives who have made this special issue possible.

I Chris King-chi Chan is Associate Professor at the Department of Sociology and Director of Social Innovation Studies, the Chinese University of Hong Kong. 4th Floor, Sino Building, Chung Chi College, The Chinese University of Hong Kong, Shatin, Hong Kong SAR (kccchan@cuhk.edu.hk).

I Éric Florence is Associate Professor at the Institute for Social Sciences Research, and at the Faculty of Philosophy and Letters, the University of Liège. Department of East Asian Studies, Place du 20-Août, 8, 4000 Liège (Eric.Florence@uliege.be).

I Jack Linchuan Qiu is Professor at the Department of Communications and New Media, the National University of Singapore, Blk AS6, \#0308, 11 Computing Drive, Singapore 117416 (jacklqiu@nus.edu.sg).

\section{References}

ATZENI, Maurizio, and Immanuel NESS (eds.). 2018. Global Perspectives on Workers' and Labour Organizations. London: Springer.

CARON, Emmanuel. 2013. "Interactions Between Chengguan and Street Vendors in Beijing: How the Unpopularity of an Administration Affects Relations with the Public." China Perspectives 1(93): 17-28.

CHAN, Anita. 2001. China's Workers Under Assault: The Exploitation and Abuse in a Globalizing Economy. Armonk: M.E. Sharpe.

CHAN, Chris King-Chi. 2010. The Challenge of Labour in China. Strikes and the Changing Labour Regime in Global Factories. Abingdon, New York: Routledge.

CHAN, Chris King-Chi, and Elaine Sio-Ineng HUI. 2014. "The Development of Collective Bargaining in China: From 'Collective Bargaining by Riot' to 'Party State-led Wage Bargaining'." The China Quarterly 217: 221-42.

CHAN, Chris King-Chi. 2020. "The World's Factory in Transition: Diversifying Industrial Relations and Intensifying Workers' Struggles in China." The China Review 20(10): 1-17.

CHAN, Jenny, Manjusha NAIR, and Chris RHOMBERG. 2019. "Precarization and Labour Resistance: Canada, the USA, India and China." Critical Sociology 45(4-5): 469-83.

CHANG, Dae-oup. 2009. "Informalising Labour in Asia's Global Factory." Journal of Contemporary Asia 39(2): 161-79.
COOKE, Fang Lee. 2005. HRM, Work and Employment in China. London: Routledge.

DE KLOET, Jeroen, Thomas POELL, Guohua ZENG, and Yiu Fai CHOW. 2019. "The Platformization of Chinese Society: Infrastructure, Governance and Practice." Chinese Journal of Communication 12(3): 249-56.

ELFSTROM, Manfred. 2019. "Two Steps Forward, One Step Back: Chinese State Reactions to Labour Unrest." The China Quarterly 240: 855-79.

FRANCESCHINI, Ivan, and Elisa NESOSSI. 2018. "State Repression of Chinese Labour NGOs: A Chilling Effect?" China Journal 80: 111-29.

FRIEDMAN, Eli, and Ching Kwan LEE 2010. "Remaking the World of Chinese Labour: A 30-year Retrospective." British Journal of Industrial Relations 48(3): 507-33.

FROISSART, Chloé. 2018. "Negotiating authoritarianism and its limits: Worker-led collective bargaining in Guangdong Province." China Information 32(1): 23-45.

GAETANO, Arianne. 2015. Out to Work: Migration, Gender and the Changing Lives of Rural Women in Contemporary China. Honolulu: University of Hawai'i Press.

GILLESPIE, Tarleton. 2010. "The politics of 'platforms'." New Media \& Society 12(3): 347-64. 
HOWELL, Jude, and Tim PRINGLE 2019. "Shades of Authoritarianism and State-Labour Relations in China." British Journal of Industrial Relations 57(2): 223-46.

KALLEBERG, Arne L., and Kevin HEWISON. 2018. "Precarious Work and the Challenge for Asia." American Behavioral Scientist 57(3): 271-88.

LAZAR, Sian, and Andrew SANCHEZ. 2019. "Understanding labour politics in an age of precarity." Dialectical Anthropology 43(1): 3-14.

LEE, Ching Kwan. 2002. "Three Patterns of Working-class Transition in China." In Jean-Louis Rocca and Françoise Mengin (eds.), Politics in China. Moving Frontiers. New York: Palgrave McMillan. 62-91.

LEE, Ching Kwan. 2016. "Precarisation or Empowerment: Reflections on Recent Labour Unrest in China." The Journal of Asian Studies 75(2): 317-33.

LEI, Ya-Wen. 2021. "Delivering Solidarity: Platform Architecture and Collective Contention in China's Platform Economy." American Sociological Review. DOI: 10.1177/0003122420979980.

MEZZADRA, Sandro, and Breitt NEILSON. 2013. Border as Method, or the Multiplication of Labour. Durham: Duke University Press.

PUN, Ngai. 2016. Migrant Labour in China. A post-socialist Transformation. Cambridge and Malden: Polity Press.

PUN, Ngai, and Huilin LU. 2010. "Unfinished Proletarianization: Self, Anger, and Class Action Among the Second Generation of PeasantWorkers in Present-Day China." Modern China 36(5): 493-519.

PUN, Ngai, and Yi XU. 2011. « Legal Activism or Class Action. The Political Economy of the "No-bos" and "No-labour Relationship" in China's Construction Industry." China Perspectives 2(86): 9-17.

QIU, Jack Linchuan. 2016. Goodbye Islave: A Manifesto for Digital Abolition. Urbana: University of Illinois Press.
SMITH, Chris, and Ngai PUN. 2018. "Class and Precarity: An Unhappy Coupling in China's Working Class Formation." Work, Employment and Society 32(3): 599-615.

STANDING, Guy. 2011. The Precariat: The New Dangerous Class. London: Bloomsburry Academic.

SUN, Ping. 2019. "Your Order, Their Labour: An Exploration of Algorithms and Labour on Food Delivery Platforms in China." Chinese Journal of Communication 12(3): 308-23.

SWIDER, Sarah. 2015. "Reshaping China's Urban Citizenship. Street Vendors, Chengguan and Struggles over the Right to the City." Critical Sociology 41(4-5): 701-16.

SWIDER. Sarah. 2017. "Informal and Precarious Work: The Precariat and China." Rural China 14: 19-41.

XUE, Desheng, and Gengzhi HUANG. 2015. "Informality and the State's Ambivalence in the Regulation of Street Vending in Transforming Guangzhou, China." Geoforum 62: 156-65.

YU Xiaomin, and Xiaojiang HU. 2012. "China's Reform of the Migrant Labour Regime and the Rural Migrants' Industrial Citizenship." In Éric Florence and Pierre Defraigne (eds.), Towards a New Paradigm of Development in 21st Century China. Economy, Society and Politics. London and New York: Routledge. 89-104.

WANG, Xu., Linchuan YANG, and Chris King-Chi CHAN. 2020. "Economic Upgrading, Social Upgrading, and Rural Migrant Workers in the Pearl River Delta." The China Review 20(1): 51-81.

WU, Qingjun, Hao ZHANG, Zhen LI, and Kai LIU. 2019. "Labour Control in the Gig Economy: Evidence from Uber in China." Journal of Industrial Relations 61(4): 574-96.

ZAVORETTI, Roberta. 2017. Rural Origins, City Lives: Class and Place in Contemporary China. Seattle, London: University of Washington Press. 